\title{
Functions of p53 in pluripotent stem cells
}

\author{
Xuemei $\mathrm{Fu}^{1 凶}$, Shouhai $\mathrm{Wu}^{2}$, Bo $\mathrm{Li}^{3}$, Yang $\mathrm{Xu}^{1}$, Jingfeng $\mathrm{Liu}^{4}$ \\ 1 The Eighth Affiliated Hospital, Sun Yat-sen University, Shenzhen 518033, China \\ ${ }^{2}$ Center for Regenerative and Translational Medicine, Guangdong Provincial Academy of Chinese Medical Sciences, The \\ Second Affiliated Hospital of Guangzhou University of Chinese Medicine, Guangzhou 510632, China \\ 3 Department of Biochemistry and Molecular Biology, Zhongshan School of Medicine, Sun Yat-sen University, Guangzhou \\ 510080, China \\ ${ }^{4}$ Cancer Research Institute, Guangdong Provincial Key Laboratory of Tumor Immunotherapy, School of Basic Medical \\ Sciences, Southern Medical University, Guangzhou 510515, China \\ $\square$ Correspondence: fxmzj2004@163.com (X. Fu) \\ Received July 2, 2019 Accepted August 29, 2019
}

\begin{abstract}
Pluripotent stem cells (PSCs) are capable of unlimited self-renewal in culture and differentiation into all functional cell types in the body, and thus hold great promise for regenerative medicine. To achieve their clinical potential, it is critical for PSCs to maintain genomic stability during the extended proliferation. The critical tumor suppressor p53 is required to maintain genomic stability of mammalian cells. In response to DNA damage or oncogenic stress, p53 plays multiple roles in maintaining genomic stability of somatic cells by inducing cell cycle arrest, apoptosis, and senescence to prevent the passage of genetic mutations to the daughter cells. p53 is also required to maintain the genomic stability of PSCs. However, in response to the genotoxic stresses, a primary role of p53 in PSCs is to induce the differentiation of PSCs and inhibit pluripotency, providing mechanisms to maintain the genomic stability of the self-renewing PSCs. In addition, the roles of p53 in cellular metabolism might also contribute to genomic stability of PSCs by limiting oxidative stress. In summary, the elucidation of the roles of p53 in PSCs will be a prerequisite for developing safe PSC-based cell therapy.
\end{abstract}

KEYWORDS p53, embryonic stem cells, induced pluripotent stem cells, genetic stability, metabolism

\section{THE PROMISE AND CHALLENGE OF PLURIPOTENT STEM CELLS IN HUMAN CELL THERAPY}

Human pluripotent stem cells (PSCs) can undergo unlimited self-renewal and differentiate into all cell types of the human body. Therefore, as a renewable source of various functional cells, PSCs hold great promise for the cell therapy of major human diseases such as neural degenerative diseases, macular degeneration, heart failure and type 1 diabetes (Blanpain and Simons, 2013; Kimbrel and Lanza, 2015). Based on the derivation method, there are two types of PSCs, human embryonic stem cells (hESCs) and induced pluripotent stem cells (iPSCs). hESCs are derived from the inner cell mass of the normal human blastocysts or human blastocysts established with somatic cell nuclear transfer technology by inserting somatic cell nucleus into the enucleated egg (Thomson et al., 1998; Tachibana et al., 2013). iPSCs are derived by nuclear reprogramming of somatic cells with various cocktails of reprogramming factors such as OCT4, SOX2, c-MYC and KLF4 (Takahashi and Yamanaka, 2006; Yu et al., 2007; Park et al., 2008). Two studies have confirmed that mouse iPSCs are fully pluripotent as ESCs (Boland et al., 2009; Zhao et al., 2009).

Significant progress has been achieved in establishing the conditions to differentiate human PSCs (hPSCs) into various lineages of biologically active cells. For example, hESC-derived cardiomyocytes can improve cardiac function in animal models after myocardial Infarction (Passier et al., 2008). hESC-derived oligodendroglial progenitors can improve neural functions in animal models after spinal cord injury (Coutts and Keirstead, 2008). In addition, hESCderived pancreatic $\beta$ cells can restore insulin independence in Type 1 diabetes animal models (D'Amour et al., 2006; Kroon et al., 2008). Cell therapies with hESC-derived cells have entered clinical trials to treat macular degeneration, spinal cord injury and Type 1 diabetes with promising results (Angelos and Kaufman, 2015). However, the major challenge that remains for hESC-based cell therapies is the 
allogeneic immune rejection of hESC-derived cells by the recipients. Using humanized mouse models reconstituted with a functional human immune system, recent studies have shown that the expression of CTLA4-Ig/PD-L1 in hESC-derived cells protects these cells from allogeneic immune rejection (Rong et al., 2014). The cancer risk of these immune evasive CTLA4-Ig/PD-L1-expressing cells could be mitigated by co-expressing a suicidal gene such as thymidine kinase (He et al., 2017). Recent studies have also suggested that the cells derived from HLA-deficient hPSCs could be protected from allogeneic immune cells in vitro or in mouse models reconstituted with human peripheral blood cells (Xu et al., 2019), however, it remains unclear whether these cells can be protected from allogeneic immune system for an extended period of time or in humanized mice reconstituted with a more vigorous immune system.

The optimization of iPSC technology has raised the hope that the cells derived from a patient's iPSCs can be immune tolerated by the same patient. However, published studies demonstrate that certain cells derived from iPSCs are immunogenic to the autologous immune system (Zhao et al., 2011, 2015), but certain lineages of cells derived from iPSCs could be immune tolerated by autologous immune system due to the overexpression of immune suppressive cytokines such as IL-10 (de Almeida et al., 2014). In addition, iPSCs exhibited various types of genetic instability such as somatic gene mutations and chromosome copy number variations, raising safety concerns of iPSC-based cell therapy (Mummery, 2011). In support of this notion, while autologous hiPSC-derived retinal pigmented epithelials have been tested in clinical trials to treat macular degeneration, the clinical trial was halted prematurely due to the genetic instability of hiPSCs (Mandai et al., 2017). The extensive expansion of hESCs in culture can increase genomic instability (Merkle et al., 2017). Therefore, to achieve the potential of human PSCs in cell therapy, it is critical to understand the mechanisms how PSCs maintain genomic stability.

\section{TUMOR SUPPRESSOR P53}

Since its discovery forty years ago, the tumor suppressor p53 gene has become the most intensively studied gene with over 80,000 relevant publications. While the complex roles of p53 remain to be elucidated, p53 is known as "the guardian of the genome" and is required to maintain genomic stability of mammalian cells (Lane, 1992; Levine, 1997). Genetic instability, a hallmark of human cancer, promotes metastasis and drug-resistance (Hanahan and Weinberg, 2011). The critical roles of p53 in tumor suppression is further underscored by the findings that the $p 53$ gene is the most frequently mutated tumor suppressor genes in human cancers with somatic mutational rate over $50 \%$ of all human cancers (Soussi and Béroud, 2001). In addition to somatic mutation of the p53 gene, the loss of wild-type (WT) p53 functions in human cancers can also be achieved through epigenetic silencing or disruption of pathways such as the ATM pathway that are required for p53 activation after DNA damage (Inoue et al., 2012; Muller and Vousden, 2013; Jain and Barton, 2018).

Structural and functional analysis have demonstrated that p53 is a transcription factor with a sequence-specific DNAbinding domain in the central region and a transcriptional activation domain at the $\mathrm{N}$-terminus (Ko and Prives, 1996). The C-terminus of p53 contains a tetramerization domain and a regulatory domain. As a transcriptional factor, p53 binds to the specific sequences in the genome and directly regulates the expression of hundreds of genes that mediate p53-dependent functions (Menendez et al., 2009). In this context, p53 activates the expression of hundred of genes, including $p 21$, MDM2, GADD45, PERP, NOXA and CYCLIN $G$. In addition, p53 also suppresses the expression of some genes, such as MAP4 and NANOG (Murphy et al., 1999; Lin et al., 2005). The importance of the transcriptional activity of p53 in tumor suppression is further underscored by the findings that the hotspot missense mutations of p53 in human cancers uniformly disrupt the normal DNA-binding activities of WT p53 (Weisz et al., 2007). In addition to the loss of WT p53 activity, p53 mutants also gain oncogenic activities in promoting tumorigenesis (Sabapathy and Lane, 2017).

p53 plays important roles in cellular responses to various stresses. In response to genotoxic and oncogenic stresses, p53 induces cell cycle arrest, apoptosis or senescence of the stressed somatic cells to prevent the passage of the genetic abnormalities to their offsprings, and thus maintaining the genomic stability of mammalian cells (Vousden and Prives, 2009; Zhao and Xu, 2010; Eischen, 2016). While p53-dependent apoptosis and cell cycle arrest are not required for p53-dependent tumor suppression (Janic et al., 2018), they could collaborate with DNA repair pathways to maintain genomic stability and tumor suppression (Janic et al., 2018). In addition, p53 plays complex roles in cellular metabolism, contributing to p53-dependent genomic stability and tumor suppression (Labuschagne et al., 2018; Kim et al., 2019; Li et al., 2019). In the absence of stresses, the activity of p53 is inhibited by MDM2 and MDMX, two transcriptional targets of p53, through protein-protein interaction (Hollstein et al., 1991; Kawamura et al., 2009; Marión et al., 2009; Lee et al., 2012). In addition, the protein levels of $p 53$ are also maintained at low levels in the absence of stresses, because several E3 ligases such as MDM2 form complex with p53, leading to the ubiquitination and degradation of p53 (Brooks and $\mathrm{Gu}, 2006$ ). Therefore, as potent negative regulators of p53 stability and activity, MDM2 and MDMX are oncogenes often overexpressed in human cancers to inhibit p53 function (Oliner et al., 2016).

Significant progress has been made to elucidate the mechanisms underlying the rapid activation of p53 in response to stresses (Fig. 1). While the mRNA levels of p53 are not significantly affected by various stresses, the rapid posttranslational modifications of p53, including 


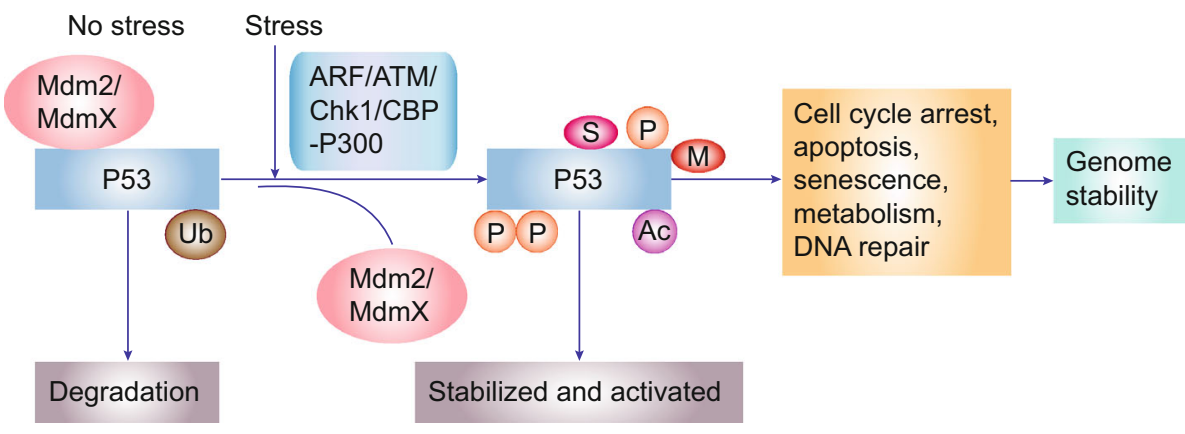

Figure 1. The roles of p53 in somatic cells. In the absence of stress, p53 is inactive and unstable due to its interaction with its transcriptional targets $\mathrm{Mdm} 2 / \mathrm{MdmX}$. In response to stresses, various posttranslational modifications of $\mathrm{p} 53$ can stabilize and activate p53 by disrupting the interaction between $\mathrm{p} 53$ and Mdm2/MdmX, leading to cell cycle arrest, apoptosis, senescence, DNA repair and metabolic change.

phosphorylation, acetylation, methylation and sumoylation, disrupts the interaction between p53 and MDM2, leading to the stabilization and activation of p53 (Craig et al., 1999; Shieh et al., 1999; Unger et al., 1999; Wu et al., 2002; Chao et al., 2003, 2006; Song et al., 2007). In addition, the acetylation of $\mathrm{p} 53$ at the C-terminus promotes its DNAbinding activity and its transcriptional activity after various stresses (Gu and Roeder, 1997; Barlev et al., 2001; Feng et al., 2005; Tang et al., 2006). The posttranslational modifications of p53 play important roles in dictating the cellular responses to various stresses. For example, the phosphorylation of p53 at Ser46 primarily activates p53-dependent apoptosis after DNA damage (Saito et al., 2002; Feng et al., 2006). In addition, the phosphorylation of p53 at Ser315 is important for suppressing NANOG expression during the differentiation of ESCs (Lin et al., 2005). The p53 activity can also be modulated by protein-protein interaction. For example, the ASPP family proteins promote the p53-mediated apoptosis by enhancing p53-dependent induction of proapoptotic genes such as PUMA (Trigiante and Lu, 2006).

\section{ROLES OF P53 IN EMBRYONIC STEM CELLS}

To achieve the clinical potential of PSCs, it is required to expand PSCs for dozens of passages before their differentiation into lineage-specific functional cells. DNA damage and oncogenic pathways can be induced during the extended self-renewal and differentiation of ESCs. In this context, the rate of spontaneous mutation is significantly lower in ESCs than in somatic cells (Cervantes et al., 2002; Xu, 2005). The disruption of the p53 gene in hESCs indicates that p53 is required for maintaining the genomic stability of hESCs (Song et al., 2010). However, in contrast to somatic cells, ESCs lack p53-dependent cell cycle $\mathrm{G}_{1} / \mathrm{S}$ checkpoint, apoptosis, and senescence (Aladjem et al., 1998). Instead, when activated, p53 induces the differentiation of ESCs by directly suppressing the expression of the critical pluripotency factor Nanog (Lin et al., 2005). Therefore, it has been hypothesized that ESCs with unrepaired DNA damage or oncogenic stress will be eliminated from the self-renewing pool due to the reduced Nanog expression, and thus ensuring the genomic stability of self-renewing ESCs (Lin et al., 2005). Consistent with this notion, ChIP analysis of p53 and p53-dependent gene expression in ESCs indicates that $p 53$ induces the expression of the differentiation-related genes and downregulates the pluripotency genes in response to DNA damage in ESCs (Li et al., 2012).

In response to the differentiation stimuli such as retinoic acid (RA), p53 is activated after being acetylated by CBP/ p300 histone acetyl transferases to induce ESC differentiation (Jain et al., 2012). In the absence of stresses, the activity of p53 must be suppressed to maintain pluripotency. In this context, the key pluripotency factor OCT4 activates the expression of histone deacetylase SIRT1, which inactivates p53 by deacetylation of p53 (Zhang et al., 2014). The extensive culture of $h E S C s$ leads to the accumulation of hESCs harboring mutated p53, raising the cancer risk of hESCs after long-term culture (Merkle et al., 2017). In this context, certain p53 mutants have gain of functions to promote the expression of pluripotent genes and thus the preferential expansion of hESCs harboring these p53 mutants (Koifman et al., 2018). Therefore, it is important to develop culture conditions that avoid the favorable selection of hESCs harboring p53 mutations during the extended culture. In summary, p53 plays a key role in maintaining genome stability of ESCs by coordinating the DNA damage response with pluripotency (Fig. 2).

p53 also plays an important role in maintaining pluripotency by regulating the expression of genes important for pluripotency. In this context, p53 activates the expression of LIF, which is important for maintaining pluripotency of ESCs (Hu et al., 2007). p53 also regulates the expression of long non-coding RNAs (LncRNAs) that are important for pluripotency. LncRNAs are longer than 200 nucleotides and often poly-adenylated without evident ORFs (Fatica and Bozzoni, 2014; Rinn, 2014). p53 directly regulates the expression of over 40 LncRNAs in hESCs, such as HOTAIRM1 and IncPRESS (p53-regulated and ESC-associated) (Jain et al., 2016). Some LncRNAs are highly expressed in hESCs and are repressed by p53 during differentiation. For example, 


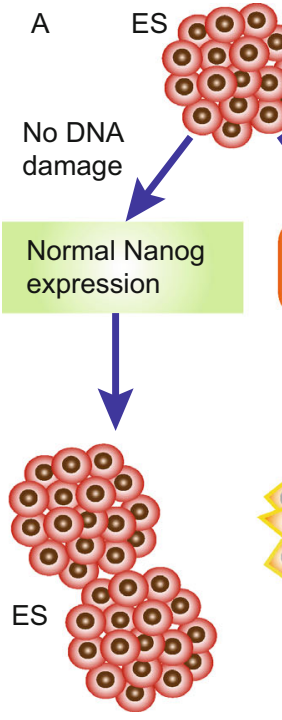

Self renewal 0100 0000 00 DNA
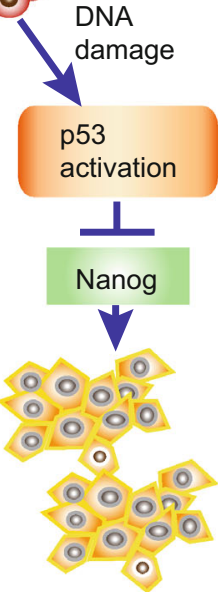

Differentiation

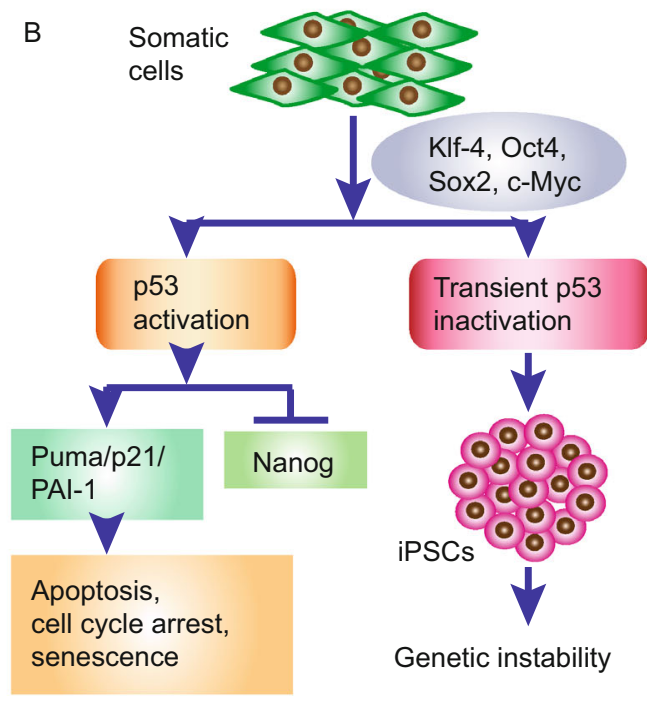

Failure to generate iPSCs

Figure 2. p53 inhibits pluripotency to maintain genomic stability of pluripotent stem cells. (A) Activation of p53 by genotoxic and oncogenic stresses in ESCs leads to the suppression of Nanog expression and the differentiation of ESCs, ensuring the genomic stability of self-renewing ESCs. (B) p53 inhibits the nuclear reprogramming of somatic cells into iPSCs. DNA damage and oncogenic stress during nuclear reprogramming activate p53, leading to cell cycle arrest, apoptosis and senescence, all of which suppress reprogramming. Transient inactivation of $p 53$ during reprogramming will greatly improve the reprogramming efficiency at the expense of genomic stability.

IncPRESS1 is involved in deacetylating H3K56ac and $\mathrm{H} 3 \mathrm{~K} 9 \mathrm{C}$ in the chromatin of ESCs by releasing SIRT6 (Jain et al., 2016). In addition, IncPRESS4, also known as TUNA, is required for maintaining pluripotency by directly binding to the promoter of Nanog, Sox2 and Fgf4 (Lin et al., 2014).

Oxidative stress, a byproduct of mitochondrial oxidative phosphorylation, is the major physiological inducer of DNA damage. In this context, p53 is important to activate the expression of anti-oxidant genes and help to reduce the levels of oxidative stress (Liu and Xu, 2010). In addition, PSCs primarily rely on glycolysis for energy and substrates for biosynthesis, providing another mechanism to maintain genetic stability by minimizing the DNA damage induced by oxidative stress (Cliff and Dalton, 2017). Recent studies have demonstrated an unexpected role of p53 in suppressing oxidative phosphorylation (Kim et al., 2019). In this context, p53 activates the expression of PUMA, which suppresses oxidative phosphorylation by reducing the mitochondrial pyruvate uptake through the disruptive interaction between PUMA and mitochondrial pyruvate carrier complex. Therefore, p53 plays diverse roles in maintaining the genomic stability of ESCs.

\section{ROLES OF P53 IN INDUCED PLURIPOTENCY}

The breakthrough of iPSC technology was first achieved by simultaneously expressing four reprogramming factors (Oct4, Sox2, Klf-4 and c-Myc) in mouse fibroblasts (Takahashi and Yamanaka, 2006). This iPSC technology is evolutionarily conserved because the same cocktail of genes can be used to reprogram somatic cells into iPSCs of various species, including rats, monkeys and human (Trounson, 2009). Other combinations of reprogramming factors have been discovered to achieve induced pluripotency, including the cocktail of Oct4, Sox2, Lin28 and Nanog (Yu et al., 2007). Oct4 and Sox2 appear to be critical for induced pluripotency and are sufficient to reprogram progenitor cells into iPSCs (Kim et al., 2008, 2009a, b; Giorgetti et al., 2009). Small chemical cocktails can also improve the efficiency of reprogramming (Shi et al., 2008; Li et al., 2009). In theory, human iPSCs (hiPSCs) derived from patients could become a renewable source of autologous cells, and therefore, have great potential in human cell therapy. Patient-specific hiPSCs also provide a unique opportunity in modeling human diseases for mechanistic studies and drug discovery (Song et al., 2010; Boulting et al., 2011; Soldner and Jaenisch, 2012; Matsa et al., 2016).

One of the key bottlenecks for IPSC technology is the extreme low efficiency of the successful reprogramming. In search for the technology to improve the reprogramming efficiency, it has become apparent that p53 is a key bottleneck for reprogramming (Zhao et al., 2008; Banito et al., 2009; Kawamura et al., 2009; Utikal et al., 2009; Smith et al., 2010). All reprogramming factors are oncogenic and often overexpressed in human cancers, especially c-Myc and Klf4 that are potent oncoproteins (Zhao and $\mathrm{Xu}, 2010$ ). The overexpression of such oncoproteins in somatic cells will activate p53, leading to cell cycle arrest, apoptosis and senescence that can all block successful iPSC 
reprogramming (Fig. 2). In addition, the activation of p53 in reprogramming cells will suppress the expression of Nanog that is required for maintaining pluripotency (Lin et al., 2005). Therefore, the silencing of the p53 gene during reprogramming has become an effective approach to increase the reprogramming efficiency (Zhao et al., 2008; Banito et al., 2009; Kawamura et al., 2009; Utikal et al., 2009; Smith et al., 2010). In addition, proteins such as Oct4 and ZSCAN4 can promote the reprogramming efficiency by inhibiting p53 (Jiang et al., 2013; Zhang et al., 2014). The silencing of the genes that are responsible for p53-dependent cell cycle arrest and apoptosis, such as p21 and Puma, can also increase the frequency of nuclear reprogramming into induced pluripotency (Lake et al., 2012; Son et al., 2013).

If the transient inactivation of p53 activity is a prerequisite of successful reprogramming into iPSCs, considering the critical roles of p53 in maintaining genomic stability of mammalian cells, this raises a serious concern for the genomic instability of iPSCs. In this context, a series of studies have demonstrated that iPSCs harbor increased genetic abnormalities (Gore et al., 2011; Chen et al., 2012; Ji et al., 2012; Li et al., 2014). In addition, the identification of the oncogenic mutations harbored by iPSCs has halted the first iPSC-based clinic trial to treat macular degeneration (Mandai et al., 2017). The genomic instability could also contribute to the immunogenicity of iPSC-derived autologous cells (Robertson et al., 2007; Zhao et al., 2011; de Almeida et al., 2014; Zhao et al., 2015; Todorova et al., 2016). Recent studies also demonstrate that mitochondrial DNA mutations in iPSCs contribute to the immunogenecity of iPSCs (Deuse et al., 2019). These safety concerns must be addressed before the clinical development of iPSC-based human cell therapy.

\section{CONCLUDING REMARKS}

Accumulating data have demonstrated that p53 is required to maintain the genomic stability of PSCs but with mechanisms distinct from somatic cells. In this context, p53 inhibits pluripotency by suppressing the expression of critical pluripotency factors, Nanog, LIF and LncRNA, and thus eliminates the stem cells with unrepaired DNA damage from the self-renewing pool. In addition, p53 activates the expression of anti-oxidant genes and suppresses oxidative phosphorylation, reducing the levels of oxidative stress that is the key physiological inducer of DNA damage. The transient loss of these roles of p53 during nuclear reprogramming of somatic cells into iPSCs contributes to genetic instability of iPSCs. The optimization of the reprogramming technology and the culture conditions of PSCs will improve the feasibility to develop PSC-based human cell therapy.

\section{ACKNOWLEDGEMENTS}

This work was supported by the National Natural Science Foundation of China (Grant Nos. 815300045, 81871197, 81930084, 81430032, U1601222), the National High Technology Research and
Development Program (863 Program) (No. 2015AA020310), Development and Reform Commission of Shenzhen Municipality (S2016004730009), Guangdong Innovative and Entrepreneurial Research Team Program (2016ZT06S638), and Shenzhen "Sanming" Project of Medicine (SZSM201602102).

\section{AUTHOR CONTRIBUTIONS}

$\mathrm{XF}$ and $\mathrm{JL}$ were responsible for the initial draft of the manuscript, whereas all authors contributed to the final edited versions.

\section{COMPLIANCE WITH ETHICS GUIDELINES}

Xuemei Fu, Shouhai Wu, Bo Li, Yang Xu and Jingfeng Liu declare that they have no conflict of interest. This article does not contain any studies with human or animal subjects performed by the any of the authors.

\section{OPEN ACCESS}

This article is distributed under the terms of the Creative Commons Attribution 4.0 International License (http://creativecommons.org/ licenses/by/4.0/), which permits unrestricted use, distribution, and reproduction in any medium, provided you give appropriate credit to the original author(s) and the source, provide a link to the Creative Commons license, and indicate if changes were made.

\section{REFERENCES}

Aladjem MI, Spike BT, Rodewald LW, Hope TJ, Klemm M, Jaenisch R, Wahl GM (1998) ES cells do not activate p53-dependent stress responses and undergo p53-independent apoptosis in response to DNA damage. Curr Biol 8:145-155

Angelos MG, Kaufman DS (2015) Pluripotent stem cell applications for regenerative medicine. Curr Opin Organ Transplant 20:663670

Banito A, Rashid ST, Acosta JC, Li S, Pereira CF, Geti I, Pinho S, Silva JC, Azuara V, Walsh M et al (2009) Senescence impairs successful reprogramming to pluripotent stem cells. Genes Dev 23:2134-2139

Barlev NA, Liu L, Chehab NH, Mansfield K, Harris KG, Halazonetis TD, Berger SL (2001) Acetylation of p53 activates transcription through recruitment of coactivators/histone acetyltransferases. Mol Cell 8:1243-1254

Blanpain C, Simons BD (2013) Unravelling stem cell dynamics by lineage tracing. Nat Rev Mol Cell Biol 14:489-502

Boland MJ, Hazen JL, Nazor KL, Rodriguez AR, Gifford W, Martin G, Kupriyanov S, Baldwin KK (2009) Adult mice generated from induced pluripotent stem cells. Nature 461:91-94

Boulting GL, Kiskinis E, Croft GF, Amoroso MW, Oakley DH, Wainger BJ, Williams DJ, Kahler DJ, Yamaki M, Davidow L et al (2011) A functionally characterized test set of human induced pluripotent stem cells. Nat Biotechnol 29:279-286

Brooks CL, Gu W (2006) p53 ubiquitination: Mdm2 and beyond. Mol Cell 21:307-315

Cervantes RB, Stringer JR, Shao C, Tischfield JA, Stambrook PJ (2002) Embryonic stem cells and somatic cells differ in mutation frequency and type. Proc Natl Acad Sci USA 99:3586-3590 
Chao C, Hergenhahn M, Kaeser MD, Wu Z, Saito S, Iggo R, Hollstein M, Appella E, Xu Y (2003) Cell type- and promoterspecific roles of Ser18 phosphorylation in regulating p53 responses. J Biol Chem 278:41028-41033

Chao C, Herr D, Chun J, Xu Y (2006) Ser18 and 23 phosphorylation is required for p53-dependent apoptosis and tumor suppression. Embo J 25:2615-2622

Chen Z, Zhao T, Xu Y (2012) The genomic stability of induced pluripotent stem cells. Protein Cell 3:271-277

Cliff TS, Dalton S (2017) Metabolic switching and cell fate decisions: implications for pluripotency, reprogramming and development. Curr Opin Genet Dev 46:44-49

Coutts M, Keirstead HS (2008) Stem cells for the treatment of spinal cord injury. Exp Neurol 209:368-377

Craig AL, Burch L, Vojtesek B, Mikutowska J, Thompson A, Hupp TR (1999) Novel phosphorylation sites of human tumour suppressor protein p53 at Ser20 and Thr18 that disrupt the binding of $\mathrm{mdm} 2$ (mouse double minute 2) protein are modified in human cancers. Biochem J 342:133-141

D'Amour KA, Bang AG, Eliazer S, Kelly OG, Agulnick AD, Smart NG, Moorman MA, Kroon E, Carpenter MK, Baetge EE (2006) Production of pancreatic hormone-expressing endocrine cells from human embryonic stem cells. Nat Biotech 24:1392-1401

de Almeida PE, Meyer EH, Kooreman NG, Diecke S, Dey D, Sanchez-Freire V, Hu S, Ebert A, Odegaard J, Mordwinkin NM et al (2014) Transplanted terminally differentiated induced pluripotent stem cells are accepted by immune mechanisms similar to self-tolerance. Nat Commun 5:3903

Deuse T, Hu X, Agbor-Enoh S, Koch M, Spitzer MH, Gravina A, Alawi M, Marishta A, Peters B, Kosaloglu-Yalcin Z, et al (2019) De novo mutations in mitochondrial DNA of iPSCs produce immunogenic neoepitopes in mice and humans. Nat Biotechnol 37:1137-1144

Eischen CM (2016) Genome stability requires p53. Cold Spring Harb Perspect Med 6:a026096

Fatica A, Bozzoni I (2014) Long non-coding RNAs: new players in cell differentiation and development. Nat Rev Genet 15:7-21

Feng L, Lin T, Uranishi H, Gu W, Xu Y (2005) Functional analysis of the roles of posttranslational modifications at the p53 C terminus in regulating $p 53$ stability and activity. Mol Cell Biol 25:5389-5395

Feng L, Hollstein M, Xu Y (2006) Ser46 phosphorylation regulates p53-dependent apoptosis and replicative senescence. Cell Cycle 5:2812-2819 Epub 2006 Dec 2811

Giorgetti A, Montserrat N, Aasen T, Gonzalez F, Rodríguez-Pizà I, Vassena R, Raya A, Boué S, Barrero MJ, Corbella BA et al (2009) Generation of induced pluripotent stem cells from human cord blood using OCT4 and SOX2. Cell Stem Cell 5:353-357

Gore A, Li Z, Fung H-L, Young JE, Agarwal S, Antosiewicz-Bourget J, Canto I, Giorgetti A, Israel MA, Kiskinis E et al (2011) Somatic coding mutations in human induced pluripotent stem cells. Nature 471:63-67

Gu W, Roeder RG (1997) Activation of p53 sequence-specific DNA binding by acetylation of the p53 C-terminal domain. Cell 90:595606

Hanahan D, Weinberg RA (2011) Hallmarks of cancer: the next generation. Cell 144:646-674
He J, Rong Z, Fu X, Xu Y (2017) A safety checkpoint to eliminate cancer risk of the immune evasive cells derived from human embryonic stem cells. Stem Cells. https://doi.org/10.1002/stem. 2568

Hollstein M, Sidransky D, Vogelstein B, Harris CC (1991) p53 mutations in human cancers. Science 253:49-53

Hu W, Feng Z, Teresky AK, Levine AJ (2007) p53 regulates maternal reproduction through LIF. Nature 450:721-724

Inoue K, Kurabayashi A, Shuin T, Ohtsuki Y, Furihata M (2012) Overexpression of p53 protein in human tumors. Med Mol Morphol 45:115-123

Jain AK, Barton MC (2018) P53: emerging roles in stem cells, development and beyond. Development 145:dev158360

Jain AK, Allton K, lacovino M, Mahen E, Milczarek RJ, Zwaka TP, Kyba M, Barton MC (2012) p53 regulates cell cycle and microRNAs to promote differentiation of human embryonic stem cells. PLoS Biol 10:e1001268

Jain AK, Xi Y, McCarthy R, Allton K, Akdemir KC, Patel LR, Aronow B, Lin C, Li W, Yang L et al (2016) LncPRESS1 is a p53regulated LncRNA that safeguards pluripotency by disrupting SIRT6-mediated de-acetylation of histone H3K56. Mol Cell 64:967-981

Janic A, Valente LJ, Wakefield MJ, Di Stefano L, Milla L, Wilcox S, Yang H, Tai L, Vandenberg CJ, Kueh AJ et al (2018) DNA repair processes are critical mediators of p53-dependent tumor suppression. Nat Med 24:947-953

Ji J, Ng SH, Sharma V, Neculai D, Hussein S, Sam M, Trinh Q, Church GM, McPherson JD, Nagy A et al (2012) Elevated coding mutation rate during the reprogramming of human somatic cells into induced pluripotent stem cells. Stem Cells 30:435-440

Jiang J, Lv W, Ye X, Wang L, Zhang M, Yang H, Okuka M, Zhou C, Zhang X, Liu L et al (2013) Zscan4 promotes genomic stability during reprogramming and dramatically improves the quality of iPS cells as demonstrated by tetraploid complementation. Cell Res 23:92-106

Kawamura T, Suzuki J, Wang YV, Menendez S, Morera LB, Raya A, Wahl GM, Belmonte JCl (2009) Linking the p53 tumour suppressor pathway to somatic cell reprogramming. Nature 460:11401144

Kim JB, Zaehres H, Wu G, Gentile L, Ko K, Sebastiano V, AraúzoBravo MJ, Ruau D, Han DW, Zenke M et al (2008) Pluripotent stem cells induced from adult neural stem cells by reprogramming with two factors. Nature 454:646-650

Kim JB, Sebastiano V, Wu G, Araúzo-Bravo MJ, Sasse P, Gentile L, Ko K, Ruau D, Ehrich M, van den Boom D et al (2009a) Oct4induced pluripotency in adult neural stem cells. Cell 136:411-419

Kim JV, Kang SS, Dustin ML, McGavern DB (2009b) Myelomonocytic cell recruitment causes fatal CNS vascular injury during acute viral meningitis. Nature 457:191-195

Kim J, Yu L, Chen W, Xu Y, Wu M, Todorova D, Tang Q, Feng B, Jiang L, He J et al (2019) Wild-type p53 promotes cancer metabolic switch by inducing PUMA-dependent suppression of oxidative phosphorylation. Cancer Cell 35(2):191-203

Kimbrel EA, Lanza R (2015) Current status of pluripotent stem cells: moving the first therapies to the clinic. Nat Rev Drug Discov 14:681-692 
Ko LJ, Prives C (1996) p53: puzzle and paradigm. Genes Dev 10:1054-1072

Koifman G, Shetzer Y, Eizenberger S, Solomon H, Rotkopf R, Molchadsky A, Lonetto G, Goldfinger N, Rotter V (2018) A mutant p53-dependent embryonic stem cell gene signature is associated with augmented tumorigenesis of stem cells. Cancer Res 78:5833

Kroon E, Martinson LA, Kadoya K, Bang AG, Kelly OG, Eliazer S, Young H, Richardson M, Smart NG, Cunningham J et al (2008) Pancreatic endoderm derived from human embryonic stem cells generates glucose-responsive insulin-secreting cells in vivo. Nat Biotech 26:443-452

Labuschagne CF, Zani F, Vousden KH (2018) Control of metabolism by p53: cancer and beyond. Biochim Biophys Acta 1870:32-42

Lake BB, Fink J, Klemetsaune L, Fu X, Jeffers JR, Zambetti GP, Xu $Y$ (2012) Context-dependent enhancement of induced pluripotent stem cell reprogramming by silencing Puma. Stem cells 30:888897

Lane DP (1992) p53, guardian of the genome. Nature 358:15-16

Lee D-F, Su J, Ang Y-S, Carvajal-Vergara X, Mulero-Navarro S, Pereira Carlos F, Gingold J, Wang H-L, Zhao R, Sevilla A et al (2012) Regulation of embryonic and induced pluripotency by aurora kinase-p53 signaling. Cell Stem Cell 11:179-194

Levine AJ (1997) p53, the cellular gatekeeper for growth and division. Cell 88:323-331

Li W, Wei W, Zhu S, Zhu J, Shi Y, Lin T, Hao E, Hayek A, Deng H, Ding $S$ (2009) Generation of rat and human induced pluripotent stem cells by combining genetic reprogramming and chemical inhibitors. Cell Stem Cell 4:16-19

Li M, He Y, Dubois W, Wu X, Shi J, Huang J (2012) Distinct regulatory mechanisms and functions for p53-activated and p53repressed DNA damage response genes in embryonic stem cells. Mol Cell 46:30-42

Li Z, Lu H, Yang W, Yong J, Zhang Z-N, Zhang K, Deng H, Xu Y (2014) Mouse SCNT ESCs have lower somatic mutation load than syngeneic iPSCs. Stem Cell Rep 2:399-405

Li L, Mao Y, Zhao L, Li L, Wu J, Zhao M, Du W, Yu L, Jiang P (2019) p53 regulation of ammonia metabolism through urea cycle controls polyamine biosynthesis. Nature 567:253-256

Lin T, Chao C, Saito SI, Mazur SJ, Murphy ME, Appella E, Xu Y (2005) p53 induces differentiation of mouse embryonic stem cells by suppressing Nanog expression. Nat Cell Biol 7:165-171

Lin N, Chang K-Y, Li Z, Gates K, Rana Zacharia A, Dang J, Zhang D, Han T, Yang C-S, Cunningham Thomas J et al (2014) An evolutionarily conserved long noncoding RNA TUNA controls pluripotency and neural lineage commitment. Mol Cell 53:10051019

Liu D, Xu Y (2010) p53, oxidative stress, and aging. Antioxid Redox Signal 15:1669-1678

Mandai M, Watanabe A, Kurimoto Y, Hirami Y, Morinaga C, Daimon T, Fujihara M, Akimaru H, Sakai N, Shibata $Y$ et al (2017) Autologous induced stem-cell-derived retinal cells for macular degeneration. N Engl J Med 376:1038-1046

Marión RM, Strati K, Li H, Murga M, Blanco R, Ortega S, FernandezCapetillo O, Serrano M, Blasco MA (2009) A p53-mediated DNA damage response limits reprogramming to ensure iPS cell genomic integrity. Nature 460:1149-1153
Matsa E, Ahrens JH, Wu JC (2016) Human induced pluripotent stem cells as a platform for personalized and precision cardiovascular medicine. Physiol Rev 96:1093-1126

Menendez D, Inga A, Resnick MA (2009) The expanding universe of p53 targets. Nat Rev Cancer 9:724-737

Merkle FT, Ghosh S, Kamitaki N, Mitchell J, Avior Y, Mello C, Kashin S, Mekhoubad S, llic D, Charlton M et al (2017) Human pluripotent stem cells recurrently acquire and expand dominant negative P53 mutations. Nature 545:229-233

Muller PAJ, Vousden KH (2013) p53 mutations in cancer. Nature Cell Biology 15:2-8

Mummery C (2011) Induced pluripotent stem cells-a cautionary note. N Engl J Med 364:2160-2162

Murphy M, Ahn J, Walker KK, Hoffman WH, Evans RM, Levine AJ, George DL (1999) Transcriptional repression by wild-type p53 utilizes histone deacetylases, mediated by interaction with mSin3a. Genes Dev 13:2490-2501

Oliner JD, Saiki AY, Caenepeel S (2016) The role of MDM2 amplification and overexpression in tumorigenesis. Cold Spring Harb Perspect Med 6:a026336

Park IH, Zhao R, West JA, Yabuuchi A, Huo H, Ince TA, Lerou PH, Lensch MW, Daley GQ (2008) Reprogramming of human somatic cells to pluripotency with defined factors. Nature 451:141-146

Passier R, van Laake LW, Mummery CL (2008) Stem-cell-based therapy and lessons from the heart. Nature 453:322-329

Rinn JL (2014) IncRNAs: linking RNA to chromatin. Cold Spring Harb Perspect Biol 6:a018614-a018614

Robertson NJ, Brook FA, Gardner RL, Cobbold SP, Waldmann H, Fairchild PJ (2007) Embryonic stem cell-derived tissues are immunogenic but their inherent immune privilege promotes the induction of tolerance. Proc Natl Acad Sci USA 104:2092020925

Rong Z, Wang M, Hu Z, Stradner M, Zhu S, Kong H, Yi H, Goldrath A, Yang Y-G, Xu Y et al (2014) An effective approach to prevent immune rejection of human ESC-derived allografts. Cell Stem Cell 14:121-130

Sabapathy K, Lane DP (2017) Therapeutic targeting of p53: all mutants are equal, but some mutants are more equal than others. Nat Rev Clin Oncol 15:13

Saito S, Goodarzi AA, Hagashimoto Y, Noda Y, Lees-Miller SP, Appella E, Anderson CW (2002) ATM mediates phosphorylation at multiple p53 sites, including Ser46, in response to ionizing radiation. J Biol Chem 277(15):12491-12494

Shi Y, Desponts C, Do JT, Hahm HS, Sch^ler HR, Ding S (2008) Induction of pluripotent stem cells from mouse embryonic fibroblasts by Oct4 and Klf4 with small-molecule compounds. Cell Stem Cell 3:568-574

Shieh SY, Taya Y, Prives C (1999) DNA damage-inducible phosphorylation of p53 at $\mathrm{N}$-terminal sites including a novel site, Ser20, requires tetramerization. Embo J 18:1815-1823

Smith ZD, Nachman I, Regev A, Meissner A (2010) Dynamic singlecell imaging of direct reprogramming reveals an early specifying event. Nat Biotechnol 28:521-526

Soldner F, Jaenisch R (2012) iPSC disease modeling. Science 338:1155-1156 
Son MJ, Son MY, Seol B, Kim MJ, Yoo CH, Han MK, Cho YS (2013) Nicotinamide overcomes pluripotency deficits and reprogramming barriers. Stem Cells 31:1121-1135

Song J, Chao C, Xu Y (2007) Ser18 and Ser23 phosphorylation plays synergistic roles in activating p53-dependent neuronal apoptosis. Cell Cycle 6:1411-1413

Song H, Chung S-K, Xu Y (2010) Modeling disease in human ESCs using an efficient BAC-based homologous recombination system. Cell Stem Cell 6:80-89

Soussi T, Béroud C (2001) Assessing TP53 status in human tumours to evaluate clinical outcome. Nat Rev Cancer 1:233-239

Tachibana M, Amato P, Sparman M, Gutierrez Nuria M, TippnerHedges R, Ma H, Kang E, Fulati A, Lee H-S, Sritanaudomchai H et al (2013) Human embryonic stem cells derived by somatic cell nuclear transfer. Cell 153:1228-1238

Takahashi K, Yamanaka S (2006) Induction of pluripotent stem cells from mouse embryonic and adult fibroblast cultures by defined factors. Cell 126:663-676

Tang Y, Luo J, Zhang W, Gu W (2006) Tip60-dependent acetylation of p53 modulates the decision between cell-cycle arrest and apoptosis. Mol Cell 24:827-839

Thomson JA, Itskovitz-Eldor J, Shapiro SS, Waknitz MA, Swiergiel JJ, Marshall VS, Jones JM (1998) Embryonic stem cell lines derived from human blastocysts. Science 282:1145-1147

Todorova D, Kim J, Hamzeinejad S, He J, Xu Y (2016) Brief report: immune microenvironment determines the immunogenicity of induced pluripotent stem cell derivatives. Stem Cells 34:510-515

Trigiante G, Lu X (2006) ASPP [corrected] and cancer. Nat Rev Cancer 6:217-226

Trounson A (2009) Rats, cats, and elephants, but still no unicorn: induced pluripotent stem cells from new species. Cell Stem Cell $4: 3-4$

Unger T, Juven-Gershon T, Moallem E, Berger M, Vogt Sionov R, Lozano G, Oren M, Haupt $Y$ (1999) Critical role for Ser20 of human p53 in the negative regulation of p53 by Mdm2. Embo J 18:1805-1814

Utikal J, Polo JM, Stadtfeld M, Maherali N, Kulalert W, Walsh RM, Khalil A, Rheinwald JG, Hochedlinger K (2009) Immortalization eliminates a roadblock during cellular reprogramming into iPS cells. Nature 460:1145-1148

Vousden KH, Prives C (2009) Blinded by the light: the growing complexity of $p 53$. Cell 137:413-431

Weisz L, Oren M, Rotter V (2007) Transcription regulation by mutant p53. Oncogene 26:2202-2211

Wu Z, Earle J, Saito S, Anderson CW, Appella E, Xu Y (2002) Mutation of mouse p53 Ser23 and the response to DNA damage. Mol Cell Biol 22:2441-2449

Xu Y (2005) A new role of p53 in maintaining genetic stability in embryonic stem cells. Cell Cycle 4:363-364

Xu H, Wang B, Ono M, Kagita A, Fujii K, Sasakawa N, Ueda T, Gee $P$, Nishikawa M, Nomura M et al (2019) Targeted disruption of HLA genes via CRISPR-Cas9 generates iPSCs with enhanced immune compatibility. Cell Stem Cell 24:566-578.e567

Yu J, Vodyanik MA, Smuga-Otto K, Antosiewicz-Bourget J, Frane JL, Tian S, Nie J, Jonsdottir GA, Ruotti V, Stewart R et al (2007) Induced pluripotent stem cell lines derived from human somatic cells. Science 318:1917-1920

Zhang Z-N, Chung S-K, Xu Z, Xu Y (2014) Oct4 maintains the pluripotency of human embryonic stem cells by inactivating p53 through Sirt1-mediated deacetylation. Stem Cells 32:157-165

Zhao T, Xu Y (2010) P53 and stem cells: new developments and new concerns. Trends Cell Biol 20:170-175

Zhao Y, Yin X, Qin H, Zhu F, Liu H, Yang W, Zhang Q, Xiang C, Hou $P$, Song $Z$ et al (2008) Two supporting factors greatly improve the efficiency of human iPSC generation. Cell Stem Cell 3:475-479

Zhao XY, Li W, Lv Z, Liu L, Tong M, Hai T, Hao J, Guo CL, Ma QW, Wang $L$ et al (2009) iPS cells produce viable mice through tetraploid complementation. Nature 461:86-90

Zhao T, Zhang Z-N, Rong Z, Xu Y (2011) Immunogenicity of induced pluripotent stem cells. Nature 474:212-215

Zhao T, Zhang Z-N, Westenskow PD, Todorova D, Hu Z, Lin T, Rong Z, Kim J, He J, Wang M et al (2015) Humanized mice reveal differential immunogenicity of cells derived from autologous induced pluripotent stem cells. Cell Stem Cell 17:353-359 